\title{
Making Environmental Accounting Work: Case of the Zimbabwe Mining Industry
}

\author{
Otekunrin Adegbola Olubukola, ${ }^{1, *}$, Samu Tafadzwa ${ }^{2}$, Sifile Obert' ${ }^{2}$, Matowanyika Kudzanai ${ }^{2}$ \\ ${ }^{1}$ Department of Accounting and Finance, Landmark University, Nigeria \\ ${ }^{2}$ Graduate School of Business, Chinhoyi University of Technology, Chinhoyi, Zimbabwe
}

Received December 15, 2020; Revised February 7, 2021; Accepted March 1, 2021

\section{Cite This Paper in the following Citation Styles}

(a):[1] Otekunrin Adegbola Olubukola, Samu Tafadzwa, Sifile Obert, Matowanyika Kudzanai , "Making Environmental Accounting Work: Case of the Zimbabwe Mining Industry," Universal Journal of Accounting and Finance, Vol.9, No.4, pp.722-734 ,2021. DOI:10.13189/ujaf.2021.090418.

(b): Otekunrin Adegbola Olubukola, Samu Tafadzwa, Sifile Obert, Matowanyika Kudzanai (2021). Making Environmental Accounting Work: Case of the Zimbabwe Mining Industry, Universal Journal of Accounting and Finance, 9(4), 722-734. DOI:10.13189/ujaf.2021.090418.

Copyright $\subseteq 2021$ by authors, all rights reserved. Authors agree that this article remains permanently open access under the terms of the Creative Commons Attribution License4.0 International License

\begin{abstract}
The research sought to find out how environmental accounting can work in Zimbabwean Mining Companies. Descriptive research design was used and mixture of qualitative and quantitative data was collected using questionnaires and interviews. Stratified purposeful sampling of 52 respondents was made up of 16 Mining Companies' executives which are dominant companies in mining gold, nickel, asbestos, coal, copper and chromite, 20 government organisations representatives and 16 mining communities' heads (8 Chiefs and 8 Headmen) were done. Community heads were interviewed and questionnaires were sent to Mining Companies' executives and government organisations representatives who were also interviewed two months after. The research reveals that government is not doing enough in fostering the implementation of environmental accounting in Zimbabwe. There is no commitment of enough resources by the government towards adoption of environmental accounting. The mining sector has been politicized, making it difficult to enforce environmental laws in this sector whilst on the other hand there are no effective laws and policies that regulate environmental accounting issues. The core existences of economic instability and political upheavals in the nation have forced firms to concentrate on their continued economic existence, doing almost nothing on environmental accounting. It was also noted that there is no proper monitoring and controlling of mining activities by law enforcers, leaving the natural environment subjected to unsustainable mining activities. There are no
\end{abstract}

environmental accounting guidelines. The research recommended that government organisations monitor and control mining activities independent of politics and commit both human and financial resources towards researching on how best environmental accounting can be implemented.

Keywords Environmental Accounting, Sustainable Strategy, Mining Industry

\section{Introduction}

The earth has been faced with dire consequences of businesses turning a blind eye on nature as they pursue economic benefits. Ainapur and Rao [1] assert that businesses operate in an environment and their economic success hinges on what the environment has. Possessions of the environment are at the mercy of these businesses as they keep posing a danger to the existence of flora and fauna [61], [77]. Unsustainable business operations have resulted in the world's most devastating calamities as well as human rights infringements [31], [61]. Williams [100] says that all creatures need to enjoy what the universe offers, not only the human being. U.S Green house Gas Inventory Report [105] and U.N. Food and Agriculture Organisation [94] have blamed industrial activities for major environmental pollutions which will continue to 
rise unless governments intervene. This has contributed immensely to ecosystem and climate changes [99], [90], [12]. Zimbabwe has no comprehensive data on levels of pollution but the pollution level is worrisome. Businesses need to consider the costs of their environmental damages and fully incorporate them in their profits computations as well as their decision making. There is ample evidence that fighting nature is fighting you [14], [24]. This is explained by devastating calamities that have befallen human being. In 2018, Zimbabwe was hit by serious floods that killed and injured an unconfirmed number of people and livestock leaving tens of thousands of people homeless. Global temperature has been increasing making life uncomfortable for earth's inhabitants [77], [7]. There has been a tremendous prise of societies, government sanctioned and non-government sanctioned organisations against firms that are a danger to the environment and the societies they operate in [65], [73]. Environmental accounting has become a pertinent growing source of concern to businesses globally as the world seeks to attain sustainable development environmentally [68], [56], [69], [101], [107].

Firms need to admit having more responsibilities besides solely meeting shareholders' expectations [15], [32], [81]. Malaysia, United Kingdom, Canada, South Africa among others nations have been heavily punishing companies for activities that cause environmental damage as well as pushing for environmental accounting audits. Environmental accounting has either been voluntary or mandatory. Mandatory environmental accounting has been accepted and supported by most organisations in America, Australia, Asia and Europe [91], [55]. In Africa a few countries such as South Africa, Kenya, Namibia and Botswana have mandated environmental accounting as requirement for companies to be listed on the stock exchange [48].

Some developed nations have introduced green tax [19] which is a tax levied on products or services that harm the environment. This is meant to discourage use or consumption of goods / products and services that are not environmentally friendly [4]. The ecosystem accounts contain maps, accounting tables and monetary value of the Ecosystem Capital [95]. The ecosystem accounting approach is grounded in the System of Environmental-Economic Accounting (SEEA) which was developed by the U.N Committee on Environmental Economic Accounting. In Zimbabwe, companies still primarily focus on profit motives [102] escalating degradation of the environment [9], [92], [62]. The Zimbabwean Mining Sector has to account for environmental costs. Contrast to other legislations, the Zimbabwean laws is silent on this. Moreover there are no sound sustainable strategies that give room for the initiation of environmental accounting as far as the Zimbabwe Mining Sector is concerned.

\subsection{Research Objectives}

(1) To establish factors that hinders the mining companies from embarking on environmental accounting.

(2) To identify if making environmental accounting work can be a strategic sustainable resource management tool in the mining sector in Zimbabwe.

(3) To determine the role of government in fostering environmental accounting in the mining sector.

(4) To ascertain the implications to the mining sector of adopting environmental accounting.

\section{Literature Review}

\subsection{Theoretical Literature}

\subsubsection{The Green Political Theory}

The theory emerged in recognition of the global environmental crisis where perpetual destruction of nature has become problematic [40]. Green Theory is embroiled with a health warning in which nature is considered to be a crucial entity in its own right. The theory is engrained with the idea that the planet earth was not created for humans alone, but all life. The theory is centered on idealising the co-existence of humans and non-humans and their relationship [76]. The green political theory advocates for an eco-centric approach and abandonment of the anthropocentric world view in which more value is placed on the survival of humans instead of the whole ecosystem [97]. The green political theory has environmental ethics at it realm. Its ethical stance stems from the philosophies developed by Gandhi and Spinoza who advocated for everyone to do things with a foresight and care for other things that exist now and their generations to come. On this basis, moral choice should then be the source of every decision [88]. The ideology behind this theory is based on creation of a world that is ecologically sustainable (a world that is rooted in social justice, environmentalism and non-violence) [73]. Human beings are a minor component on earth hence questioning the idea that humans are more superior to anything that is constituted in nature. The theory seeks to address socio-ecological problems hence strengthening the capacity to attain sustainability globally. The green political principles drive for sustainable environmental management which saves nature.

\subsubsection{The Stakeholder Theory}

The popular word "Stakeholder" first appeared in 1963 through the Stanford Institute of research [16] countering the ideology that the stockholders are the only group that management should focus on when making decisions [38]. Edward Freeman, the pioneer of Stakeholder Theory describes stakeholders as internal and 
external groups of people that have and can be influenced by the activities of the businesses. The theory seeks to devise ways in which organisations can reap maximum benefits by being responsive to all stakeholders. The fundamentals of the theory insinuate that there should be existence of relationships between organisations and their various stakeholders, and there should be equality between different stakeholders [60], [75]. The stakeholder concept requires businesses to consider the welfare of societies, nature and be ethical. The theory is a driving force for firms to be more concerned and conscientious in every function they undertake taking into consideration the effects of their activities on its stakeholders and the natural environment hence achieving social and environmental accounting [22]. Businesses that apply the stakeholder theory are perceived to be more environmentally considerate and they strive to embark on activities which do not harm the environment [75].

\subsubsection{Institutional Theory}

The theory suggests that organisations conform to well-known rules as well as norms of governing institutions to get support and be perceived as legitimate [83]. The theory explains show changes in societal values, technological improvement, as well as regulations can influence decisions about environmental accounting [3]. In this case organisations exist in an institutional environment and these institutions create expectations that enhance legitimacy practices for firms and they have powers to influence individual company's activities [93]. These institutions have the power to stop or shape organisational behaviours, decisions and goals [64], [53], [74]. The institutional environment pushes the companies into focusing on the implementation of environmental accounting practices that can meet the expectations of these institutional organisations. Institutional theory clearly show firm's actions or behaviour can be governed by its institutional environment [23].

\subsection{Empirical Review}

\subsubsection{Factors Hindering the Implementation of Environmental Accounting}

Impediments to environmental accounting practices can be country specific, continent specific, firms specific or industry's specific [103]. One of the factors that hinder the implementation of environmental accounting process is that it is a complicated accounting procedure [59]. The rise of many initiatives towards environmental accounting by many different international bodies has led to no shared consensus among practitioners hence lacking comparability [35], [79], [18]. It has been difficult for firms to decide on which framework to adopt; currently there is unavailability of a single framework that guides environmental accounting and reporting process. There is no agreed basis of evaluating the quality and reliability of environmental issues [86], [96], [35], [71].

Lack of adequate resources and dedication towards implementation of environmental accounting has been encountered by many nations [103]. George, Siti-Nabiha, Jalaludin \& Abdalla [39] articulate that insufficient funds, absents of appropriate human capital, unavailability of expertise and knowledge are the major problems in implementing environmental accounting practices. Environmental accounting is considered to be at its infant stage in most countries hence there is limited expertise in this area and this proves to be problematic when it comes to its implementation especially in developing nations [17], [72]. In some cases, lucrative business projects out compete sustainable projects especially in developing nations, making finance the greatest challenge in adopting environmental accounting in such scenarios [54].

Non-alignment of thoughts and goals between financial teams and environmental advocates is a significant barrier to implementation of environmental accounting. There is a divergence of priorities in most cases between sustainability teams and financial team members within organisations. The financial management team is seen to be more influential and possess the power to key decision making, hence sustainability teams tend to have little or no influence as decision makers hence making environmental accounting of little or no effect. This leads to environmental issues not being fully incorporated into the business strategy [5], [80]. Environmental issues are not easily measured and quantified. Without the existence of an apparent means to price environmental costs such as pollution and climate change it is difficult to include these issues as part of accounting and decision making. This then implies that even when firms try to implement environmental accounting, they may not be fully aware of the actual costs and problems associated with their activities in the long run [51].

\subsubsection{Strategies of Implementing Environmental Accounting}

The ecosystem accounts contain maps, accounting tables and monetary value of the Ecosystem Capital [95] The ecosystem accounting approach is grounded in the System of Environmental-Economic Accounting (SEEA) which was developed by the U.N Committee on Environmental Economic Accounting (UN System of Environmental Economic Accounting (SEEA) [95]. The ecosystem accounts produced in Netherlands presented a comprehensive over view of ecosystem capital which included services provided by the ecosystem and the interdependencies of the economic activities to these ecosystems. This has allowed the measurement in change of the ecosystem capital and has assisted the nation in environmental management [26]. The introduction of Green Tax in the United States, which is levied on products or services that harm the environment, has been very successful such that more than $10 \%$ of the revenue generated by the federal government is from Green Tax. 
This has pushed companies to be environmentally friendly [30], [46].

\subsubsection{The Role of Governments in Implementing Environmental Accounting}

Governments are gradually getting involved in fostering the adoption of environmental accounting especially in Asia, America and Europe, where protection and promotion of social objectives are considered to be very crucial [98]. In UK, environmental accounting has gained prominence such that it has become government's priority on public agendas [6]. In particular the governments have an important role in developing legislations and regulations that controls the implementation and adoption as well as continued monitoring of environmental accounting practices [25].The success of environmental accounting is in the government's ability in providing a framework for regulations and its ability to enhance the means by which to monitor compliance by firms. Governments have an important role in environmental accounting standard setting through the provision of policy framework and making sure international financial reporting standard is complied with [106]. Canadian and Philippians governments have been very successful in doing that [49]. South Africa has also come up with similar legislations which seek to support the King 111 code of governance which also advocate for environmental and social accounting [50]. Governments are also in a better position in pushing for SEEA principles and countries such as Botswana, Namibia and Australia are leading in pushing for the adoption of SEEA in Environmental accounting practices. More so the government stands a better place in raising awareness and builds the pillars for environmental accounting implementation by organisation as they do have their sources and influence. Germany started to consider the adoption of environmental accounts in the1980s and very successful results were yielded [57]. The more people are aware of environmental problems caused by unsustainable business operations, the more likely that attention will be diverted towards identifying solutions to address these environmental challenges. This implies that people have to be made aware of the negative implications of being reckless to the environment. This can be broadcasted on radio and television stations.

Some governments in Europe have also been acting as providers of information to firms that desire to implement Environmental Accounting, Netherlands being the best in doing so [8]. The Dutch government when the implementation of Environmental Accounting was still at its initial stage, sourced information from other nations which were already practicing Environmental Accounting and made it available to local firms through initiatives that included websites, radio and television channels that informed the society on how to adopt Environmental Accounting. The Netherlands Government aided businesses in addressing challenges they faced as they try to implement Environmental Accounting. The provision of state-issued information and guidance aided business to be aware of predominant Environmental Accounting issues and provided the basis for strategy formulation in tackling the problems faced by firms in implementing environmental accounting.

Where environmental accounting has been implemented, the governments in such nations have to a larger extend been involved in environmental accounting standard setting through the provision of policy framework, which pushes organisations beyond minimum legal standards [78]. Government plays a crucial role in policy-making which is crucial in promoting environmental accounting at national level, encouraging tightening of laws that enhance environmental accounting. Canada has enacted numerous policies that seek to promote environmental accounting implementation. Since the inception of the Canadian Environmental Protection Act in 1999 several policies have been introduced and several amendments have been made to the act and more additions have been engrossed in the act so as to address current environmental issues [87].

Integrating and collaborating with other international organisation that are pushing for environmental protection such as the United nation is one of the ways in which developed nations have managed to make environmental accounting work in their nations. This has been made possible by entering into agreements and treaties. Canada and Norway have entered in several of such agreements with various organisations such as the Organisation for Economic and Cooperation and Development (OECD) and the North American Commission for Environmental Cooperation. The government of China, Us and Germany have been the leaders in promoting environmental accounting through the introduction of clean technology. In United States, the federal government has invested more than \$1.8 billion in clean technology and more money resources are expected to be channelled into the adoption of clean technology [78]. Helping business in adopting clean technology is also another way in which government scan foster for environmental accounting.

\subsubsection{Implications of Adopting Environmental Accounting}

\subsubsection{Benefits of Environmental Accounting}

Environmental accounting accrues an extensive spectrum of benefits to the business organisation that implements it [10], [37]. One of the benefits environmental accounting is that it will reduce pressure from stakeholders. It is evident that businesses are facing continued increase in pressure from stakeholders over their need to recognise the damage they are causing to the environment. Environmental accounting helps companies avoid such pressures and encourage firms to innovate and come up with ways of reducing environmental harm and strategies to enhance sustainable resource management 
[10]. Environmental accounting at least makes firms think about the environment as they operate. Boston College [10] noted that nowadays customers prefer products from socially responsible companies despite the variations in prices that might exist. Neu, Warame and Pedwel [67], early writers on environmental accounting agrees that environmental accounting can be a means by which organisation effectively manage external impression. Environmental accounting enhances clarity and trust between stakeholders and the firm reporting. Environmental accounting facilitates safeguard for the environment bringing about eco-efficiencies [13]. Environmental accounting is agreed to ensure mutual benefits to the society and the business [11], [33], [27].

\subsubsection{Critics to Environmental Accounting}

There have been questions as to whether the environmental accounting rhetoric matches the actual practices on the ground [42]. Some critics take environmental accounting employed by corporate as a "green wash" to enhance a good corporate image whilst covering up for their bad doings [45], [89]. Deegan [19] concluded that this has led to piece meal Environmental accounting leaving the bad side of corporate that they perceive to be detrimental to the reporting entity. This is supported by [41] who say that management capture, records and control the environmental issues to be disclosed without the involvement of external stakeholders. This gives room for management to collect and disseminate information it deems appropriate to advance the corporate agenda rather than being transparent and accountable to the society it serves.

Hrasky and Jones [47] as well as Dizik [21] argue that in most business models real environmental problems are invisible hence excluded in strategic decision making processes. Dizik[21] supported the writer saying that the concept of environmental accounting is not at the realm of many businesses' strategic plans even though it has been popular, hence environmental accounting is considered as a market gimmick instead of being a real concern for firms. Dizik [21] claims that environmental accountability is a curtain to hide behind.

There is disharmony of facts on whether environmental accounting has impacts on financial performance of businesses [58]. Environmental accounting information is not easy to understand and to tag a monetary value on it [52]. Practicing sustainability is almost impractical in a world where financial decision makers and shareholders cannot easily be persuaded to channel resources toward activities designed to benefit others stakeholders [85]. Serafeim [85] reasoned that there is no credibility and reliability in the data provided in environmental accounting reports compared to financial reports. Sustainability issues are more qualitative and unspecific making it difficult to measure the information and compare it with other firms [19]. Even with the existence of the GRI guidelines and SEEA there is still lack of proper standards to guide the measurability and comparability of environmental data [44]. There are also no legal rules to enforce the adoption of environmental accounting at global level. Adopting Environmental accounting at the same time trying to be profitable is even harder and the business of businesses is to make profit only.

\section{Methodology}

A descriptive research design approach was used making use of mixed research technique in line with [34], [106]. Purposive sampling technique was used. The sampling was based on respondents' experience, expertise and knowledge of the study area. Questionnaires were used to collect data from 16 companies' senior representatives who are dominants companies in mining gold, nickel, asbestos, coal, copper and chromite and 20 government representatives- from 6 government agencies- and interviews were conducted on 16 community representatives- 8 Chiefs and 8 Headmen. Follow up interviews conducted on the companies and government representatives two months after receiving their filled questionnaires. Mining companies' questionnaire had a Cronbach's Alpha of 0.855 whilst that of government representatives had 0.726 . Both instruments were reliable as they were between 0.7 and 0.9 as dictated by Cronbach's Alpha standards [66].

\section{Results and Discussion}

\subsection{Factors Hindering Environmental Accounting Adoption in the Mining Sector}

\subsubsection{Lack of Knowledge about Environmental Accounting}

The findings from the questionnaires revealed that non-implementation of environmental accounting have little to do with lack of knowledge about environmental accounting. The majority of the respondents from both the mining companies and government agencies clearly understood what environmental accounting is. This was also confirmed by the follow up interviews in which no variations to the responses were noted. $75 \%$ of mining companies' management clearly understands what environmental accounting is whilst $18.75 \%$ had a general understanding of environmental accounting and only $6.25 \%$ of them had no knowledge of it. On the same issue, about $80 \%$ of respondents from government agencies were of the view that non-implementation of environmental accounting in the mining industry has little to do with lack knowledge of the genre whilst the remaining $20 \%$ were of the idea that lack of knowledge is a contributor to 
non-implementation. The findings therefore showed that non-adoption of environmental accounting is largely explained by other factors other than lack of knowledge about Environmental Accounting.

\subsubsection{Reluctance of the Mining Firms}

$43.8 \%$ of the mining companies' representatives indicated that there were no measures being implemented in the mining sector while $31.3 \%$ said little was being done in pursuing environmental accounting though these measures were not specified when the same set of respondents was interviewed. Only $12.5 \%$ indicated that some mining companies have put measures to address environmental accounting issues. The remaining $12.5 \%$ indicated mining companies were not mandated to pursue environmental accounting. Almost similar responses were provided by government representatives, among which $50 \%$ of them stipulated that mining firms are too reluctant to implement environmental accounting measures and no measures have been implemented. 30\% suggested that there are insignificant measures being pursued environmentally by the mining sector whilst $20 \%$ argued that firms are not reluctant in adopting environmental accounting; however, this portion of government respondents' view was contrary to what community members $(100 \%)$ who acceded that mining firms were being reluctant in implementing environmental accounting. This surmounts the conclusion that there is reluctance in putting measures that eradicate environmental problems at company and national level.

\subsubsection{Value that Organisation Place on Environmental Accounting Related Issues}

Supporting the fact that there is reluctance in adopting environmental accounting within the mining sector, the study revealed that $56.25 \%$ of mining companies do not place value on environmental accounting while $25 \%$ place moderate importance, $12.5 \%$ consider it important and only $6.25 \%$ consider it very important. This did not only confirm that there is reluctant in adoption of environmental accounting but there is a general non-adoption of environmental accounting in the mining sector which is linked to less value being place on the subject. The results are in line with the findings of [20].

\subsubsection{Ineffectiveness of Environmental Regulatory Bodies}

Regulatory bodies are not doing enough in enforcing environmental accounting practices as indicated by $50 \%$ of the mining executives that stipulated that there are no independent regulatory bodies that assess the environmental accounting practices. $12 \%$ of the executives confirm that regulatory bodies assess environmental accounting issues while $38 \%$ of the executives were indifferent. On the other hand all of the government agencies strongly argued that there is too much politicisations of the mining sector such that their effort in regulating environmental issues is disrupted. This is also in line with what the majority of community leaders agreed with when interviewed. The majority of community leaders agreed that hardly ever see independent regulatory bodies regulating mining activities in their areas and that the mining sector is politicized. The findings therefore led to the conclusion that regulatory bodies are being ineffective in monitoring and controlling mining activities.

\subsubsection{Law Enforcement by the Government}

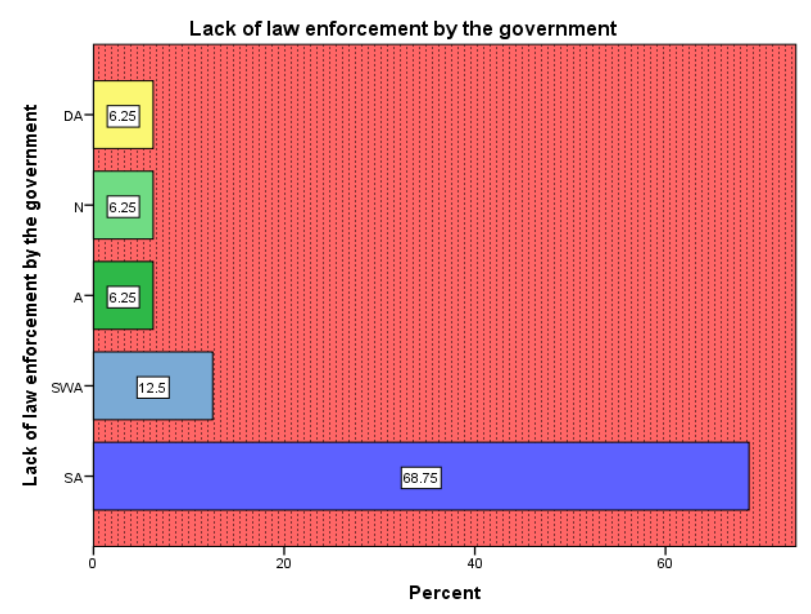

Figure 1. Lack of law enforcement by the government as an impediment

The findings give strong evidence that government is not doing enough in enforcing laws that ensure the implementation of environmental accounting. As illustrated in figure 1 above $87.5 \%$ of the mining sector's representatives agreed that there is lack of law enforcement by the government in fostering the adoption of environmental accounting. Thus $68.75 \%$ strongly agreed, $12.5 \%$ somewhat agreed and the other $6.25 \%$ simply agreed that there are no government laws that enforce the implementation of environmental accounting. Only $6.25 \%$ were in conflict with this ideas they disagreed, this small portion of the mining representatives acceded that the limited level of adapting environmental accounting is entirely caused by factors other than lack of enforcement laws whilst those that were neutral did not suggest other possible reasons that are hindering environmental accounting in Zimbabwe. Deliberating on the same issue, $70 \%$ of government agencies assented that it is very challenging to enforce environmental accounting issue in Zimbabwe where the mining sector is controlled by politicisations and where the mining sector is the key driver of economic growth. The findings led to the conclusion that lack of law enforcement by the government is also an impediment to the adoption of environmental accounting with in the mining sector. Zhuwarara [104] had earlier found that Zimbabwe lacks the enforcement of mining sector legal and policy framework. The findings also support [103] and [59].

In support of the findings above, the research also revealed that current government policies lack not just the 
enforcement but adequacy also. Fifteen (15) of the sixteen (16) respondents from the government agencies consented that the existing government policies are not adequate in pushing for environmental accounting. They affirmed that the government is too reluctance to introduce policies that mandate the implementation of environmental accounting in Zimbabwe. This explains why firms do not put in to effect environmental accounting issues. These results were also found by [25] who noted that governments need to set appropriate legislation for environmental accounting initiatives to succeed.

\subsubsection{Measuring and quantifying environmental issues}

The study also sought to establish if measuring and quantifying environmental accounting issues are problematic to the mining firms. Both questionnaire and interview responses showed that $56.3 \%$ of the mining executives agreed that the absence of the means to measure and quantify environmental issues is hampering environmental accounting efforts. The findings support [79] and [18].

\subsubsection{Organisational internal barriers to the implementation}

Cumulatively $87.5 \%$ of respondents noted that the absence of ways of classifying costs on environmental basis, lack of environmental accounting training programs and costs implications of environmental accounting hinder the implementation of environmental accounting practices. The findings agree with [39],[17],[72].

\subsection{Can Environmental Accounting be a Sustainable Strategy}

$81 \%$ of the total sample agreed with Boston College Centre for Corporate Citizenship and EY's 2013 survey which revealed that environmental accounting is a crucial area that should be embraced as part of sustainable goals [29]. There is a general agreement that environmental issues are sustainability issues even though there is no empirical evidence to show support for this conclusion. There is no will to have this realised. This suggests that there is a sense of greedy and selfishness amongst the current miners in Zimbabwe and they know this fact.

\subsection{Establishing the Role of Government in Environmental Accounting Adoption}

One of the major objectives of the research was to establish the role of government in fostering the implementation of environmental accounting. Respondents advocated for green tax laws, environmental accounting guidelines, mandatory environmental accounting policy, environmental accounting education and training programs, fiscal support of environmental accounting initiatives, incentives for complying companies as well as environmental audits. There is consensus that the government has to intervene in environmental accounting initiatives to be successful. Individual entities have proved to be greedy and selfish. This is a confirmation of [49] findings.

\subsubsection{Strategies of Making Environmental Accounting Work}

Table1. Strategies that can Make environmental Accounting Work in the mining sector

\begin{tabular}{|c|c|c|c|c|c|}
\hline & & Frequency & $\%$ & Valid\% & Cum\% \\
\hline \multirow{6}{*}{ Valid } & $\begin{array}{c}\text { Develop methods of } \\
\text { accounting for ecosystem }\end{array}$ & 4 & 25.0 & 25.0 & 25.0 \\
\hline & Adopt SEEA guidelines & 3 & 18.8 & 18.8 & 43.8 \\
\hline & \begin{tabular}{|c} 
Introduce carbon accounting \\
project
\end{tabular} & 2 & 12.5 & 12.5 & 56.3 \\
\hline & $\begin{array}{c}\text { Adopt Green or environmental } \\
\text { tax }\end{array}$ & 3 & 18.8 & 18.8 & 75.0 \\
\hline & $\begin{array}{c}\text { Collaborate with international } \\
\text { groups that promote the } \\
\text { implementation of } \\
\text { environmental accounting }\end{array}$ & 4 & 25.0 & 25.0 & 100.0 \\
\hline & Total & 16 & 100 & 100. & \\
\hline
\end{tabular}

As shown by the table above, development of methods of accounting for ecosystem and collaboration with international groups that advocate for environmental accounting practices were considered effective strategies in making environmental accounting work followed by adoption of green tax laws, adoption of SEE A guidelines and lastly introduction of carbon accounting projects in that order.

\subsection{Implications to the Mining Sector for Adopting Environmental Accounting}

There has been a general consensus that adoption of environmental accounting does not increase the overall expenses but, increases customer loyalty, reduces unnecessary litigation, reduces company wastages and increases operation efficiencies and increases company goodwill as once said by [67],[2],[36]. Environmental accounting is also seen as reducing profits. Environmental accounting is however not away of enabling capital inflow. This view contradicts ACCA 2013 survey results.

\subsubsection{Benefits of Environmental Accounting to the Government and Community}

Both the mining and the government agencies representatives consensually perceived environmental accounting to be a way to address social injustice between communities and mining firms and can be away for the government to achieve the United Nation 2030 Agenda for sustainability and poverty eradication through combating climate change and reducing public spending by the government. All 16 community leaders also acceded that environmental accounting can allow them to core exist with mining firms drawing from each other mutual benefits that will ensure sustainability. 


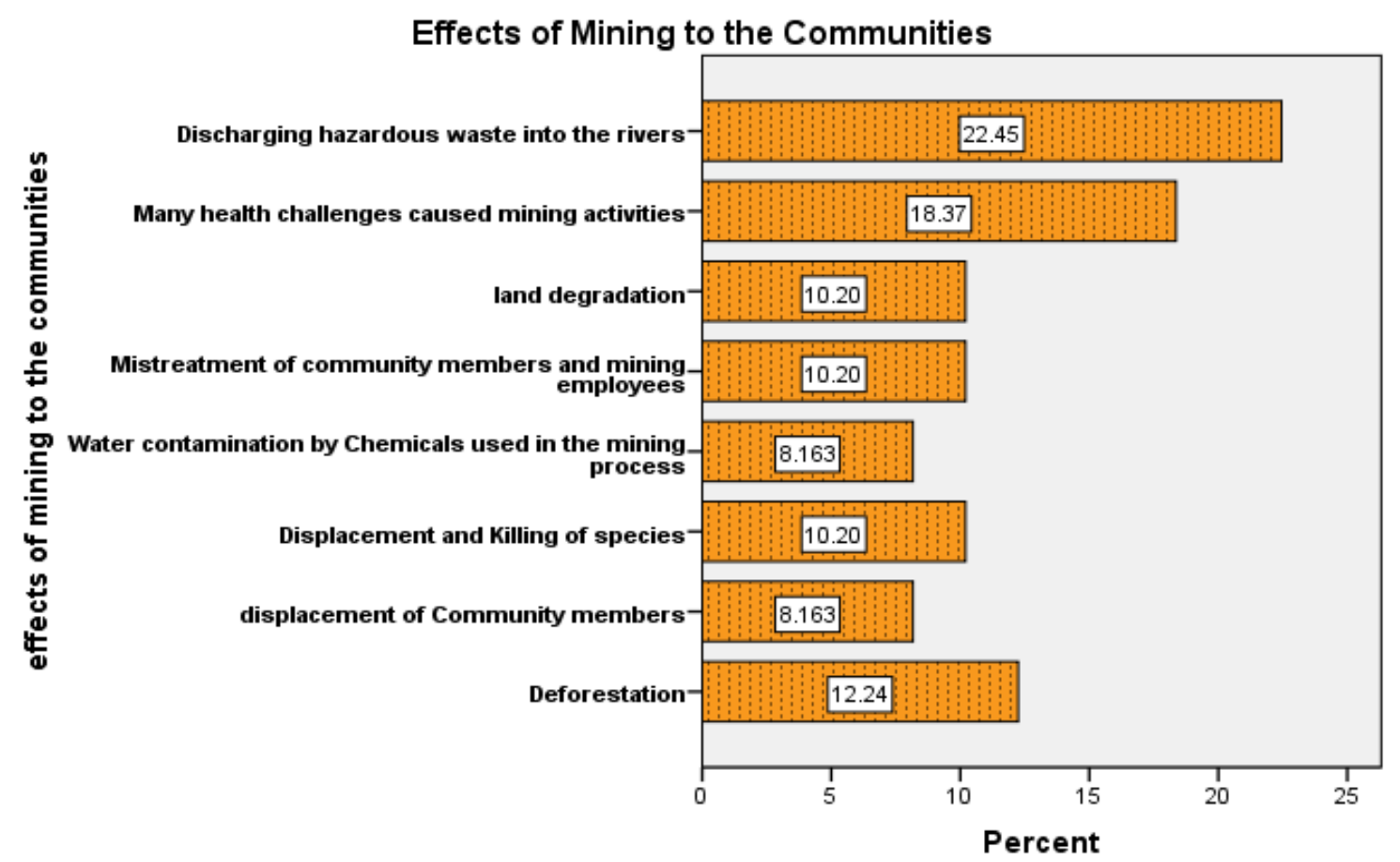

Figure 2. Effects of mining to Local communities

\subsubsection{Effects of Mining to the Communities}

During the interviews community leaders mentioned more than just one effect of mining activities to their community environment and considered the mining firms cruel as they are reaping the communities' resources. According to community leaders they have no control over mining companies and everything about their operations have been politicised such that they are left doing whatever the deem necessary to the environment. As shown in figure 2 above, the most frequently identified problem in mining communities is how the mining companies discharge hazardous waste in a manner that are harmful people and animals. This was followed by air and noise pollution, land degradation, invading farming land, in humane treatment of mine worker and deforestation.

\section{Conclusions and Implications of the study}

\subsection{Conclusions}

Non-implementation of environmental accounting in Zimbabwean Mining Companies is not a result of lack of knowledge about environmental accounting. It is a result of lack of resources and dedication towards the implementation by both the government and the mining firms, lack of ways to measure and quantify environmental costs, non-alignment of thoughts and goals between management, the communities involved and government, as well as lack of law enforcement on the part of government and its law enforcing agents. Mining firms are greedy and inconsiderate of future generations' needs. The Zimbabwean Government is not doing enough to control and monitor environmental activities through legal frameworks which should be mandating the mining sector in to implementing environmental accounting. Politicisation of mining activities and corruption are impediments to environmental accounting implementation.

There is urgent need to develop systems of ecosystem accounting. The adoption of SEE A guidelines, implementing Green Tax Laws, collaborating with international boards advocating for environmental accounting, facilitating environmental accounting education and training programs, providing incentives for mining companies to embark on environmental accounting practices, mandating environmental accounting practices, developing environmental accounting guidelines or standards, allocating resources towards the implementation of Environmental accounting, and conducting regular environmental audits are options the Zimbabwean Government can consider enhancing environmental accounting. However for the options to work there is need to depoliticise the mining sector, foster environmental auditing and reduce corruption levels.

Implementation of environmental accounting enhance corporate image, increases customer loyalty and reduces litigations. Environmental accounting helps investors to make investment decisions that are beneficial to company and the general public. Implementing environmental accounting help the government to address social 
injustices between communities and mining firms and combat climate change. Environmental accounting allows the core existence of mining firms and the community drawing benefits from each other hence ensuring sustainable existence of mining operations.

\subsection{Implication to Policy}

The findings reflected that there are poor policy frameworks and regulations in Zimbabwe that regulate mining activities as well as environmental issues and lack of enforcement to the current laws and policies. The Zimbabwean Government's Ministry of Mines and Ministry of Environment need to develop adequate and effective policies that regulate the impact of mining activities on the environment. There is need for the development of environmental accounting guide lines or standards meeting the requirements of environmental accounting practices to enable the implementation of environmental accounting in Zimbabwe. There is need to seriously consider laws mandating the adoption of environmental accounting in Zimbabwe. Policies toward environmental audit should also be developed and implemented by regulatory boards and government ministries.

\subsubsection{Implications to Practice}

For environmental accounting to work, company plans, objectives, missions and goals should focus on reducing the negative impact on the environment. There is need for companies to develop measures which comply with available international environmental initiatives. There is need for continue devaluation of mining technologies opting for technologies with less environmental impacts. The Zimbabwean Government need to come up with natural resources accounts. Individual mining entities need to come up with their internal environmental accounts .Environmental accounting shapes investors' decisions towards profitable as well as sustainable companies. Environmental accounting addresses social injustices between communities and mining firms, allowing core existence of nature and its elements.

\subsubsection{Implications to Theory}

The research is a building stone for future researches on environmental accounting in Zimbabwe and other developing nations. The research pushes the embracing of Institutional and Green Theories identified as main theories driving the implementation of environmental accounting.

\subsection{Recommendations}

All activities impacting on the natural environment should be accounted qualitatively and quantitatively. Firms need to establish corporate commitments to good business practices that include environmental sustainability issues. Mining Companies should abide to environmental laws and voluntarily engage in environmental accounting guided by available international environmental accounting initiatives. The government should have strict environmental accounting laws including mandating environmental accounting and environmental audits. The Zimbabwean Government needs to depoliticise itself from mining operations so that it can act as an independent regulator of mining activities. The Government need to allocate resources toward the adoption of environmental accounting and establish boards that develop environmental accounting guiding standards that will enable environmental accounting.

\subsection{Further Studies}

The researchers have managed to identify ways of making environmental accounting work as sustainable strategy but efforts to do so are impeded by non-existence of proper guidelines and difficulties in measuring environmental cost. Further research needs to establish means of measuring environmental costs as well as initiating environmental accounting and reporting standards. Future research needs to focus on all industrial sectors including the in formal mining sector. This research revealed that environmental accounting erodes profits and does not increase the costs of the business. These contradicting findings leave an unexplained gap requiring further inquiries.

\section{Acknowledgement}

All researchers and non-researchers that contributed to this paper are highly appreciated.

\section{Conflict of Interest}

There is no conflicting of interest on this study as it is not funded by any source.

\section{REFERENCES}

[1] R. Ainapur, B. R. Rao. Sustainable reporting in Indian foundries. EPRA International Journal of Economic and Business Review, Vol. 2, No. 5, pp. 16-21, 2014.

[2] E. J. Akhaiyea. Design and bases of environmental accounting in oil and gas and manufacturing sectors in Nigeria, 2009. (Doctoral dissertation). Retrieved from http//:dspace.covenantuniversity.edu.ng/.../10

[3] A. Ball, R. Craig. Using neo-institutionalism to advance social and environmental accounting, Critical Perspectives on Accounting, Vol. 21, No. 4, pp. 283-293, 2010. 
[4] J. Beaudoin, Y. Chen, D.R. Heres, K.H. Kheiravar, G.E. Lade, F. Yi, W. Zhang, C.Y.C. Lin Lawell. Environmental Policies in the Transportation Sector: Taxes, Subsidies, Mandates, Restrictions, and Investment, Economics Working Papers: Department of Economics, Iowa State University. 18012, 2018. Retrived: https://lib.dr.iastate.edu/ econ_workingpapers/54.

[5] M. Bennett, P. James. The green bottom line: environmental accounting for management: current practices and future trends Jesudason, Routledge, London, U.K, 2017.

[6] S. Bennett, M.D. Hudson, S. Kemp. Stakeholder perceptions of Environmental Management Plans as an environmental protection tool for major developments in the UK. Environmental Impact Assessment Review, Vol.56, pp. 60-71, 2016.

[7] E. Blakemore. Six irrefutable pieces of evidence that prove climate change is real. Popular science, 2017. Retrieved from https://www.popsci.com/evidence-climate-change-is-r eal/

[8] V.J. Bodegraven. Towards natural capital accounting the netherlands, 2018. Retrieved from https://www.unenvironm ent.org/news-and-stories/story/towards-natural-capital-acco unting-netherlands

[9] C. Bonnie. Revisiting the reform process of african mining regimes, Canadian Journal of development studies, Vol. 30, No. 1-2, pp. 197-217, 2010.

[10] Boston College. The enrst and young excellence current-use fund for accounting and management, 2016. Retrieved from https://www.bc.edu/content/dam/files/top/advancement/gen eral/FY17/EYReport2016.pdf

[11] J. Boyd. The benefits of improved environmental accounting: an economic framework to identify priorities, Resources for the Future, Washington, DC, U.S.A. Discussion Paper 98-49, 1998.

[12] F. Bridoux, J.W. Stoelhorst. Stakeholder relationships and social welfare: a behavioural theory of contributions to joint value creation. Academy of Management Review, Vol. 41, No. 2, pp. 229-251, 2016

[13] E. Cargno, G.J.L. Micheli, P. \& Trucco. Eco-efficiency for sustainable manufacturing: an extended environmental costin method. Journal Production Planning \& Control: The Management of Operations, Vol. 23, No.2-3, pp. 34-144, 2012.

[14] G.H. Chang, G.J. Wen. Communal dining and the Chinese famine of 1958- 1961. Economic Development and Cultural Change, Vol. 46, pp.1-34, 1997.

[15] L.J. Christensen, A. Mackey, D. Whetten. Taking responsibility for corporate social responsibility: the role of leaders in creating, implementing, sustaining, or avoiding socially responsible firm behaviors. The Academy of Management perspectives, Vol. 28, No. 2, pp. 164-167, 2014.

[16] M. Clayton. The origin of stakeholders in: the influence agenda. Palgrave Macmilan, London, 2014.

[17] L. Coady, J. Lister, C. Strandberg, Y. Ota. The Role of Corporate Social Responsibility in the International Shipping Sector. Report for the Northern European Symposium on
CSR in Shipping, pp. 1-44, 2013.

[18]D. Crowther. A social critique of corporate reporting: a semiotic analysis of corporate financial and environmental reporting, Routledge, London, U.K, 2018. (https://doi.org/10.4324/9781315186047)

[19]C. Deegan. Twenty five years of social and environmental accounting research within critical perspective of accounting, Hhits, misses and ways forward, Critical perspective on accounting. Elsevier, Vol. 43, No.C, pp. 65-87, 2017.

[20]C. Deegan, M. Rankin, P. Voght. Firms' Disclosure Reactions to Social Incidents: Australian Evidence, Accounting Forum. Vol. 24, No. 1, pp. 101-130, 2000.

[21] A. Dizik. Why corporate social responsibility can backfire, Chicago Booth Review: Research-Driven Insights on Business, Policy, and Markets, 2018. Available from: https://review.chicagobooth.edu/strategy/2018/article/why-c orporate-social-responsibility-can-backfire

[22] J.P. Doh, N.R. Quigley. Responsible Leadership and Stakeholder Management: Influence Pathways and Organizational Outcomes. The Academy of Management Perspectives, Vol. 28, pp. 255-274, 2014. http://dx.doi.org/10.5465/amp.2014.0013

[23] V. Doshi, P. Khokle.. An institutional perspective on corporate social responsibility. Vikalpa: The Journal for Decision Makers, Vol. 37, No.2, pp. 98-102, 2012.

[24] B. Drake. The worst drought and famines in history, The weird history rankers, 2019. Retrieved february 4, 2019, from weird history rankers: https://www.ranker.com/list/theworst-droughts-and-famines-in-history/drake-bird

[25] A. Duit, P.H. Feindt, J. Meadowcroft. Greening Leviathan: the rise of the environmental state?, Environmental Politics, Vol, 25, No.1, pp. 1-23, 2016. DOI: 10.1080/09644016.2015.1085218 To link to this article: https://doi.org/10.1080/09644016.2015.1085218

[26] C. Duku, H. Rathjens, S. J. Zwart, and L. Hein. Towards ecosystem accounting: a comprehensive aproach to modelling multiple hydrological ecosystem services., Hydrology Earth System Sciences, Vol. 19, pp. 4377-4396, 2015.

[27] P.A. Egbunike, M.N. Eze. Must firms adopt environmental accounting? Adoption challenges in Nigeria, Trends Economics and Management, Vol. 30, No. 3, pp. 9-19, 2017.

[28] Ernst \& Young LLP and the Boston College Center for Corporate Citizenship. Value of Sustainability Reporting: A Study by EY and Boston College, pp. 1-29, 2013. Retrived from: https://www.eycom.ch/en/Publications/20131022-Val ue-of-sustainabilityreporting/download.

[29] Ernst \& Young (2013). Value of sustainability reporting: A study by Ernst \& Young LLP and the Boston College Center for Corporate Citizenship, EYGM Limited

[30]EPA United States Environmental Protection Agency. An introduction to environmental accounting as a business management tool: key concepts and terms, Design for the Environment Program, Environmental Accounting Project, pp. 1-26, 2017

[31] M. Epstein, A. Buhovac, J. Elkington, H. Leonard. Making Sustainability Work: Best Practices in Managing and 
Measuring Corporate Social, Environmental, and Economic Impacts. Berrett-koehler publishers., 2017.

[32] M.O. Erdiaw-Kwasie, K. Alam. Towards understanding digital divide in rural partnerships and development: A framework and evidence from rural Australia, Journal of Rural Studies, Vol. 43, pp. 214-24, 2016.

[33] C.E. Ezeagba, J.C. Rachael, U. Chiamaka. Environmental accounting disclosures and fiinacial performance: a study of selected food and beverage companies in nigeria (2006-2015), International Journal of Academic Research in Business and Social Sciences, Vol. 7, No. 9, pp. 162-174, 2017.

[34] A.O. Otekunrin, D.G. Fagboro, T.I. Nwanji, F.F. Asamu, O. B. Ajiboye, J.A. Falaye. Performance of deposit money banks and liquidity management in Nigeria, Banks and Bank Systems, Vol. 14, No.3, pp. 152-161, 2019.

[35] T. Feng, L. Cummings, D. Tweedie. Exploring integrated thinking in integrated reporting - an exploratory study in Australia, Journal of Intellectual Capital, Vol. 18, No. 2, pp. 330-353, 2017.

[36]F. Tai, S. Chuang. Corporate Social Responsibility. iBusiness, Vol. 6, pp. 117-130, 2014. DOI: http://dx.doi.org/10.4236/ib.2014.63013.

[37] M. Czinkotaa, H.R. Kaufmannb, G. Basilec, M.A. Ferric. For-Benefit Company (fBComp): An innovative social-business model. The Italian case, Journal of Business Research, Vol. 119, pp. 377-387, 2020.

[38] E. Freeman, J.S. Harrison, A.C. Wicks, B.L. Parmar, S. Colle. Stakeholder theory:the state of the art, Business Ethics Quarterly, Cambridge: cambridge unvirsity press, Vol. 22, No.1, pp. 179-185, 2012.

[39] R.A. George, A.K. Siti-Nabiha, D. Jalaludin, Y.A. Abdalla. Barriers to and enabler of sustainability integration in the performance management system of oil and gas company, Journal of clean production,Vol. 136, Part A, pp. 197-212, 2016.

[40] Global Greens. Charter of the Global Greens. Dakar: Global Greens, 2012. Retrieved from https://www.globalgreens.org/sites/globalgreens.org/files/G G_charter_2012_english.pdf. Accessed 22/06/16.

[41] R H. Gray, M. MIlne. Perhaps the Dodo should have accounted For Human Beings? Accounts of humanity and (its) extinction, Accounting, Auditing \& Accountability Journal , Vol. 31 , No. 3 , pp. 826-848, 2018. https://doi.org/10.1108/AAAJ-03-2016-2483

[42] R. Gray, C. Adams, D. Owen. Social and Environmental Accounting and the Critical Accounting Project(s): In search of creative tension? in R. Roslender (Ed) The Routledge Companion of Critical Accounting (London: Routledge) pp. 241-257, 2017. ISBN: 978-1-138-02525-7 (hbk) 978-1-315-77520-3 (ebk)

[43] R. Greenberg. The Environmental Impact of Manufacturing from the Industrial Revolution to Automation and Everything, 2014. Retrieved April 20, 2017, from http://cerasis.com/2014/09/08/manufacturingand-the-enviro nment/.

[44] N. Gunnningham, D. Sinclair. Leaders and laggards:next generation environmental regulations, London, Routledge, 2017. DOI: https://doi.org/10.4324/9781351282000

[45] J. F. Henri, O. Boiral, M. J. Roy. Strategic cost management and performance: The case of environmental costs. The British Accounting Review, Vol. 48, No. 2, pp. 269-282, 2016.

[46] M.A.T. Harchegani, N. Dahmardeh. Green tax effect on Iran's health sector: A general equilibrium approach. Iranian Journal of Economic Studies, Vol. 6, No. 2, pp. 251-270, 2017.

[47] S. Hrasky, M. Jones. Lake pedder: accounting, environmental decision-making, nature and impression management. Accounting forum,Vol. 40, No.4, pp. 285-299, 2016.

[48] International Integrated Reporting Council (IIRC). Towards integrated reporting, Communicating value in the $21 \mathrm{st}$ century, 2011. Available at:http://hipinvestor.com/wpconten t/uploads/Integrated-Reporting.pdf (accessed 15 May 2015)

[49] INTOSAI Working Group on Environmental Auditing. Environmental Accounting:Current Status and Options for SAIs, 2010. Available at: http://iced.cag.gov.in/wp-content/ uploads/2013/02/INTOSAI-envr-aaccounting-current-status. pdf

[50] C. Kamunda, M. Mathuthu, M. Madhuku. Health Risk Assessment of Heavy Metals in Soils from Witwatersrand Gold Mining Basin, South Africa, International Journal of Environmental Research and Public Health, Vol. 13, pp. 663, 2016. DOI: 10.3390/ijerph13070663.

[51]Z. Karimi, M. Dastgir,. M.A. Salehi. Analysis of factors affecting the adoption and use of Environmental Management Accounting to provide Conceptual Model, International Journal of Economics and Financial Issues, Vol. 7, No.3, pp. 555-560, 2017.

[52] Y. Kim. Consumer responses to the food industry's proactive and passive environmental csr, factoring in price as csr tradeoff. Journal of business ethics. Vol. 140, pp. 307-321, 2017.

[53]E. Martínez-Ros, R. Kunapatarawong Influences of institutional pressures on corporate social responsibility attitude and corporate social responsibility outcomes, Departamento de economía de la empresa universidad carlos iii de madrid, 2013.

[54] J.S.L. Lam, J.M. Lim. Incorporating Corporate Social Responsibility in Strategic Planning: Case Of Ship-Operating Companies, International Journal of Shipping and Transport Logistics, Vol. 8, No. 3, pp. 273-293, 2016.

[55]D C. Langevoort. Disasters and Disclosures. Georgetown University Law Center. 2018. Downloaded from: https://scholarship.law.georgetown.edu/facpub/2024

[56] H. Latan, R. Noonan. Partial Least Squares Path Modeling: Basic Concepts, Methodological Issues and Applications. Springer International Publishing, Cham. 2017.

[57] J. Longhurst.Delivering environmental protection through local authorities. In: Environmental Protection UK Annual Conference 2017, Birmingham, England, 9 November 2017. Available from: http://eprints.uwe.ac.uk/33783 
[58] X. Luo, H. Wan, S. Raithel, Q. Zheng. Corporate Social Performance, Analyst Stock Recommendations, and Firm Future Returns, Strategic Management Journal , Vol. 36, No. 1, pp. 123-136, 2015.

[59] K. Maas, S. Schaltegger, N. Crutzen. Integrating Corporate Sustainability Assessment, Management Accounting, Control, and Reporting. Journal of Cleaner Production, Vol.5 No.3 , pp. 237-248, 2016

[60] R. Marens, A. Wick. Getting Real: Stakeholder Theory, Managerial Practice, and the General Irrelevance of Fiduciary Duties Owed to Shareholders, Business Ethics Quarterly, Cambridge University Press, 2015.

[61] Masuku, M., Selepe, M \& Ngcobo, N. The Socio-economic Status as a Factor Affecting Food (In) Security in Rural Areas, uThungulu District Municipality, Kwa-Zulu Natal, South Africa, Journal of Human Ecology, Vol. 58, No. 1,2, pp. 57-66, 2017.

[62] M. Mathe, A. Phiri. The Impact of Mining on the Environment in Gwanda District Zimbabwe: A Case Study Of Blanket Mine, Imperial Journal of Interdisciplinary Research, Vol. 2, No. 5, 2016.

[63]D. Matten, J. Moon. "Implicit” and "Explicit” CSR: A Conceptual Framework for a Comparative Understanding of Corporate Social Responsibility. Academy of Management Review, Vol. 33, No. 2, pp. 404-424, 2008.

[64] J.W. Meyer, B. Rowan. Institutional organizations: formal structure as myth and ceremony, American Journal of Sociology, Vol. 83, pp. 340-63, 1977.

[65] P, Mudu, E. Beck. Navigating Scientific Routes to Risk Assessment: a Tortuous Path, Journal of Risk Research, Vol. 15, No.10, pp.1217-1222, 2012.

[66] S.K. Namdeo, S.D. Rout Calculating and interpreting cronbach's alpha using Rosenberg assessment scale on paediatrician's attitude and perception on selfesteem, International Journal of Community Medicine and Public Health, Vol. 3, pp. 1371-1374, 2016.

[67]D. Neu, H. Warame, K. Pedwel. Managing public impressions: environmental accountings in annual reports. Accounting organisations and society, Vol. 23, No. 3, pp. 265-282, 1998

[68] A.E. Nielsen, C. Thomsen. Reviewing corporate social responsibility communication: A legitimacy perspective. Corporate Communications. Vol. 23, No. 4, pp. 492-511, 2018. . https://doi.org/10.1108/CCIJ-04-2018-0042

[69] D.T. Viet, N.T. Ngo. The Settlement Practice of Environmental Disputes Involving Foreign Investors in Vietnam - Two Sides of the FDI Coin, Asian Year Book of International Law, 2017, Available at SSRN: https://ssrn.com/abstract=3451307

[70] OECD. Climate and Carbon: Aligning Prices and Policies, Environment Policy Paper, OECD Publishing, Paris. 2013.

[71] I.O. Olalekan, O.O. Jumoke. Identifying Barriers to Environmental Management Accounting Practices: A Comparative Study of Nigeria and South Africa. The Business And Management Review, Vol. 9, No. 1, pp. 168-179, 2017.

[72] N. Osmanagić Bedenik, D. Prebežac, I. Strugar, P. Barišić.
The Challenges of Controlling and IT Support in Non-financial Reporting, International journal of industrial engineering and management, Vol. 10, No.1, pp. 21-29, 2019.

[73] P. Robbins. Political ecology. A critical introduction, Oxford: Blackwell, 2012.

[74] B.G. Peters. Institutional Theory in Political Science: The New Institutionalism, 3rd edn, Continuum, New York, 2012.

[75] R. Phillips. Stakeholder Theory and Organizational Ethics. Berrett-Koehler, San Francisco, CA, 2003.

[76] J. Barry. Green Political Theory. Political Ideologies, 4th edition, London: Routledge, 2014.

[77] N. Reed. The Effects of Industrialization on Animals, sciencing.com. Retrieved from https://sciencing.com/effects -industrialization-animals-8519359.htm. 13 December 2020.

[78] E.J. Ringquist. Environmental protection at the state level: Politics and progress in controlling pollution. United States: N. P., 1993. Web

[79] S. Schaltegger, R. Burritt. Contemporary environmental accounting: issues, concepts and practice. Routledge, London, 2017.

[80] S. Schaltegger, R. Burritt, H. Petersen. An Introduction to Corporate Environmental Management. Striving for Sustainability. Routledge, London, 2017.

[81] S. Schaltegger, I.Á. Etxeberria, E. Ortas. Innovating Corporate Accounting and Reporting for Sustainability Attributes and Challenges, Sustainable Development, Vol. 25, No. 2, pp. 113-122, 2017.

[82] M. Schröter, D.N. Barton, R.P. Remme, L. Hein. Accounting for capacity and flow of ecosystem services: a conceptual model and a case study for Telemark, Norway, Ecological Indicators, Vol. 36, pp. 539-551, 2014.

[83]W.R. Scott. Institutions and Organizations. SAGE Publications, Thousand Oaks, 1995.

[84]W.R. Scott. Institutions and Organizations: Ideas and Interests, 3rd ed. Sage Publications, Los Angeles, CA, 2008.

[85] M.N. Khan, G. Serafeim, A. Yoon. Corporate Sustainability: First Evidence on Materiality. Harvard Business School Working Paper, No. 15-073, March 2015

[86] W. Setthasakko. Barriers to the development of environmental management accounting: An exploratory study of pulp and paper companies in Thailand,EuroMed Journal of Business, Vol. 5, No. 3, pp. 315-331, 2010.

[87] B. Smith. Canada: Environmental Issues, Policies and Clean Technology". AZoCleantech. 13 December 2020. $<$ https://www.azocleantech.com/article.aspx?ArticleID=563 $>$..

[88] Spinoza and the Deep Ecology Movement. In: Drengson A. (eds) The Selected Works of Arne Naess. Springer, Dordrecht, 2005. https://doi.org/10.1007/978-1-4020-45196_121

[89] Y. Sun Two essays on CSR, Greenwashing and Accounting, A dissertion proposal, Graduate School-Network, Rutgers, the State of University of New Jersey, 2018. 
[90]F. Taubert, R. Fischer , J. Groeneveld, S. Lehmann, M.S. Müller, E. Rödig, T. Wiegand, A. Huth. Global patterns of tropical forest fregmentation, Nature, No. 554, pp. 519-522, 2018. https://doi.org/10.1038/nature25508

[91] The Hauser Institute for Civil Society. Corporate Social Responsibility Disclosure Efforts By National Governments and Stock Exchanges. Initiative for Responsible Investment, 2015. Retrieved from https://iri.hks.harvard.edu/files/iri/file s/corporate_social_responsibility_disclosure_3-27-15.pdf

[92] The Zimbabwean Financial Gazette. Harare: Herald, 2012.

[93] P. H. Thornton. Markets from Culture: Institutional Logics and Organizational Decisions in Higher Education Publishing. 2004.

[94] U.N. Food and Agriculture Organisation (FAO) FAO and SDG Indicators: Indicators: Measuring up to the 2030 Agenda for Sustainable Development. Rome: Food and Agriculture Organization of the United Nations, 2017.

[95] United Nation. System of Environmental Economic Accounting. 2019. Available online: http://unstats.un.org/un sd/envaccounting/seea.asp (accessed on 4 November 2020).

[96] K.S.K.. Venkateswara, D.V. Rama. Sustainability Reporting Practices in India: Challenges and Prospects. K L U Business School Central University of Sikkim, Twelfth AIMS International Conference on Management, India, 2015.

[97] A. Vincent. Green political theory 2018.

[98] I. Weibust. Green Leviathan: The Case for a Federal Role in Environmental Policy, Routledge, London, U.K, 2016.

[99] M. Weisse, L. Goldman. Global Tree cover loss rose 51 percent in 2016. World Resour. Inst. 2017. Available online: http://www.wri.org/blog/2017/10/global-tree-cover-loss-ros e-51-percent-2016 (accessed on 14 December 2019)

[100] A.D. Willians. Earth was created for all life not just humans, 2019.

[101] Wolrd bank group.. Guidance notes on tools for pollution management (2019, march 31). Retrieved from getting to green-a sourcebook of pollution management policy tools for growth and competitiveness: www.worldbank.org

[102] T. Wushe. 2017 Corporate community engagement (cce) in zimbabwe's mining industry from the stakeholder theory perspective. University of South Africa, Pretoria, <http://hdl.handle.net/10500/14154>

[103] K.F. Yuen, J.M. Lim. Barriers to the Implementation of Strategic Corporate Social Responsibility in Shipping, The Asian Journal of Shipping and Logistics, Vol. 32, No. 1, pp. 49-57, 2016.

[104]K.S. Zhuwarara. An assessment of the impact of Zimbabwe's mining policy, legislative and institutional framework on acquisition and oversight of diamond mining rights, University of Pretoria, Dissertation, 2017. http://hdl.handle.net/2263/60116

[105] U.S Greenhouse Gas Inventory Report (2017),

[106] Yuta Hoshino, "Effect of IFRS Adoption on Corporate Performance Measurement: Analysis of Japanese Manufacturing Companies," Universal Journal of Accounting and Finance, Vol. 5, No. 4, pp. 78 - 90, 2017. DOI: 10.13189/ujaf.2017.050402.

[107] Yiannis K. Yiannoulis, "Literature Review on the Hellenic Auditing and Accounting Environment before, during and after the Crisis Period," Universal Journal of Accounting and Finance, Vol. 7, No. 2, pp. 43 - 49, 2019. DOI 10.13189/ujaf.2019.070202 